\title{
Deformation and fracture of alumina ceramics with hierarchical porosity
}

MiHAIL V. GRIGORIEV - Institute of Strength Physics and Materials Science of RAS, Tomsk Polytechnic University / grv@ispms.ru

NIKoLAI L. SAVCHENKO - Institute of Strength Physics and Materials Science of RAS - savnick@ispms.ru

Tatiana Yu. SABLINA - Institute of Strength Physics and Materials Science of RAS - sabtat@ispms.ru

EMESE KUROVICS - Institute of Ceramics and Polymer Engineering, University of Miskolc - fememese@uni-miskolc.hu

IRINA N. SEVOSTYANOVA - Institute of Strength Physics and Materials Science of RAS - sevir@ispms.ru

SvetLana P. BUYAKOVA - Institute of Strength Physics and Materials Science of RAS, Tomsk Polytechnic University - sbuyakova@ispms.ru

LÁszLó A. GÖMZE - Institute of Ceramics and Polymer Engineering, University of Miskolc - femgomze@uni-miskolc.hu

SERGEI N. KULKOV - Institute of Strength Physics and Materials Science of RAS, Tomsk Polytechnic University • kulkov@ms.tsc.ru

Érkezett: 2018. 01. 15. - Received: 15. 10. 2018. - https://doi.org/10.14382/epitoanyag-jsbcm.2018.4

\section{Abstract}

The compression behavior of Al203 ceramics with a hierarchical pore structure was studied. The hierarchical pore structure included the pores of three types: coarse porosity with a size of 80 to $100 \mu \mathrm{m}$, fine porosity with a size of 14 to $15 \mu \mathrm{m}$, and intermediate interblock porosity comprised of elongated (110-120 $\mu \mathrm{m})$ porous microchannels formed as a result of zonal isolation during sintering.

It is shown that the obtained hierarchical porous structure causes the formation of a hierarchical deformation structure in the volume of ceramics and leads to a decrease in the extent of destruction processes from the macroscopic scale in the case of unimodal ceramics to the microscale destruction comparable with the sizes of the blocks formed during sintering. At fixed values of the pore space, the studied ceramics with hierarchical pore structure shows a noticeably higher compressive strength as compared to the ceramics with a unimodal porosity. Keywords: deformation, fracture, pore ceramic, alumina.

\section{Introduction}

Deformation behavior of porous brittle media, in particular, ceramics, geological materials, etc., is currently studied in detail primarily for ceramic with unimodal pore-size distribution (unimodal porosity), made by the method of partial sintering [1-7]. At the same time, it has been shown that threshold values of the pore-space volume exist for such materials at which both the deformation and subsequent fracture modes change substantially. The macroscopic strain-induced behavior of high-porosity ceramics is depicted by characteristic stressstrain curves that exhibit a fairly long portion corresponding to inelastic strain due to microcracking. The latter contribute to accumulation and movement of local volumes of the material into the pore space in addition to a portion describing linear elastic strain seen at low stresses. Such deformation behavior is called pseudo-plastic because of the shape of the stress-strain curve similar to plastic metallic and elastic polymeric materials $[5,6,8]$. Moreover, it has been shown that the character of deformation depends on the mean pore size as well $[5,6,9]$.

It was shown in [5] that the mechanism of micromechanical instability of rod or cellular structures formed during sintering in high-porosity ceramics can be manifested. Meanwhile, the study of the evolution of defects in the volume of such brittle materials is of considerable interest in terms of generation
Mihail V. GRIGORIEV,

has PhD since 2007. At present time he is a post doctoral fellow in Institute of Strength Physics and Materials Science of Siberian Branch of the Russian Academy of Science under guidance Prof. Kulkov.

Nikolai L. SAVCHENKO, PhD Education: 1987: Tomsk Polytechnic Universityengineer.1991-1994: Institute of Strength Physics and Materials Science of the Russian Academy of Sciences in Tomsk - PhD student. 1995: PhD.degree from the Institute of Strength Physics and Materials Science of the Russian Academy of Sciences in Tomsk.

Tatiana Yu. SABLINA, has PhD Education since 1989 at present she is working at the Tomsk State University and Institute of Strength Physics and Materials Science of the Russian Academy of Sciences in Tomsk.

Emese KUROVICS, is graduated in the University of Miskolc, Department of Ceramics and Silicate Engineering as a material engineer, where she actually continues her study as PhD student under supervision of Prof. L. A. Gömze.

Irina N. SEVOSTYANOVA PhD Education: 1987: Tomsk Polytechnic Universityengineer.1993-1996: Institute of Strength Physics and Materials Science of the Russian Academy of Sciences in Tomsk - PhD student. 2001: PhD.degree from the Institute of Strength Physics and Materials Science of the Russian Academy of Sciences in Tomsk. Field of research: Structure and mechanical property of porous ceramics based zirconia and alumina

Svetlana P. BUYAKOVA,

is Doctor of Sciences since 2008, full Professor since 2013. She is specialist in material sciences of ceramic and ceramic matrix composites based on oxides and carbides. She is author and co-author of more than 100 papers. Now, she is chief scientist in IS PMS RAS and professor in Tomsk State University and Tomsk Polytechnic University. Her teaching experience: Introduction to materials science, Fundamentals of materials engineering, Materials and their applications.

László A. GÖMZE,

is establisher and professor of the Department of Ceramics and Silicate Engineering in the University of Miskolc, Hungary. He is author or coauthor of 2 patents, 6 books and more than 300 scientific papers. Recently, he is the chair of the International Organization Board of ic-cmtp5 the 5th International Conference on Competitive Materials and Technological Processes (2018).

Sergei N. KULKOV

is professor of the Tomsk State University and head of Department of Ceramics in the Institute of Strength Physics and Materials Science of the Russian Academy of Science since 1989 His research works are represented in 5 books, more than 150 articles, 18 patents and many International Symposiums and Conferences. At present he is head of department „Theory of Strength and Mechanic of Solids", member of "The American Ceramic Society” of "The APMI International" and the DYM AT Society (France).

of hierarchies of the deformation structure and subsequent destruction. The synthesis of ceramics having a hierarchical porous structure with spatial and interpenetrating structures of different configurations (cells, channels, shells, etc. $[1,2,10]$ ) is considered to be a very most promising means for creation of porous ceramic materials, as similar elements in the structure can give rise to unusual deformation modes of hierarchically 
organized structures as compared with conventional brittle materials $[1,2,11]$. Nevertheless, there is a lack of such studies because of difficulties arising upon the synthesis of such systems. Typically, a system of pores with sizes commensurate with the grain size, or with larger pore sizes when pore-forming agents are added, develops upon sintering ceramics. These methods include the methods of chemical pore formation, the methods of burnable additives, the foaming methods, etc. $[1,2]$. On the other hand, the effect of "zonal segregation" as a consequence of the active shrinkage of samples upon sintering is known [11], which consists in the partition of a sintered sample into regions (blocks) that are significantly larger than the mean particle size of the sintered material. Typically, the following two types of pore structures can be formed: one is determined by the interparticle porosity and the other by the porosity between blocks. Usually, these structures are formed randomly; however, the zonal segregation effect during sintering can be achieved by the addition of relatively large particles of pore-forming agents, which will be removed in the initial stage of sintering.

The study of the difference in the damage evolution in the volume of porous ceramics with unimodal and hierarchical porosity on different structural scales and their subsequent fracture depending on the strain rate, degree of constrained strain, etc., are of considerable academic interest in the hierarchical deformation and fracture structures formed in ceramics and rocks.

The present paper undertakes to investigate the deformation and fracture of porous alumina ceramics with unimodal and hierarchical porosity.

\section{Experimental procedure}

Two types of samples were obtained: unimodal porosity, obtained due to the partial sintering of ceramic powders, and with a hierarchically organized pore structure obtained by introducing a pore-forming agent into the mixture.

Samples with unimodal distribution of pores and different values of porosity 17 and $70 \%$ were produced from $\mathrm{Al}_{2} \mathrm{O}_{3}$ powder by thermal decomposition of water solutions of metal nitrates in highfrequency discharge plasma [3]. Electron microscopic examination under scanning and transmission electron microscopes revealed that the powders were largely composed of hollow spherical particles in sizes of about several micrometers. The size of the crystallites constituting the powders was $\sim 20-50 \mathrm{~nm}$.

A $3 \%$ polyvinyl alcohol solution was added to the initial powders. The mixture was pressed in steel die molds at a pressure of $100 \mathrm{MPa}$, using a hydraulic press. The resultant specimens were cylindrical (10 $\mathrm{mm}$ in diameter and $15 \mathrm{~mm}$ in height) in shape. Sintering was performed in air in the temperature range from 1000 to $1600^{\circ} \mathrm{C}$ for an isothermal annealing time of $1 \mathrm{~h}$. The heating and cooling rates were $240{ }^{\circ} \mathrm{C} / \mathrm{h}$.

Samples with a hierarchically organized pore structure were obtained using the method of slip casting of $\mathrm{Al}_{2} \mathrm{O}_{3}$ powder, to which spherical particles of high-density ultra-high molecular weight polyethylene (UHMWPE) with a mean particle size of $100 \mu \mathrm{m}$ in amounts of 15,20 , and $25 \mathrm{wt}$. \% were injected with the subsequent removal of the polymer bond and sintering in air at temperatures of 1400,1500 , and $1600^{\circ} \mathrm{C}$ by isothermal exposure.
The density of the sintered specimens was measured by a geometric method. The residual porosity was calculated from theoretical-to-measured density ratio. The structure of the samples after sintering was studied by the methods of optical and scanning electron microscopy. The size of pores and the distance between them in the ceramics after sintering and after compression tests were measured by means of a scanning electron microscope. Several micro images and at least 400 pores were measured for each sample. The two- dimensional pore-size distribution obtained in such a way was transformed into a three-dimensional distribution using Saltykov's main stereo metric equation [12].

Cylindrical samples were subjected to mechanicalcompression tests on a Devotrans universal testing machine at a loading rate of $2 \times 10^{4} \mathrm{~s}^{-1}$. The stiffness of the loading system was determined before testing. A rectilinear portion corresponding to the elastic strain of the specimens was identified in the stress $(\sigma)$ - strain $(\varepsilon)$ curves. The effective elastic moduli were found from the initial rectilinear portions of the $\sigma-\varepsilon$ curves plotted upon the compression testing of the specimens.

\section{Results and discussion}

After sintering, the ceramics with unimodal porosity had a porosity of $17-70 \%$. The pore structure of $\mathrm{Al}_{2} \mathrm{O}_{3}$ ceramics with unimodal porosity sintered at $1400^{\circ} \mathrm{C}$ and $1600^{\circ} \mathrm{C}$ is shown in Fig. 1.a,b. With an increase in sintering temperature, along with decrease in pore space volume, an increase in the average pore size was observed due to the consolidation of fine pores into larger ones.

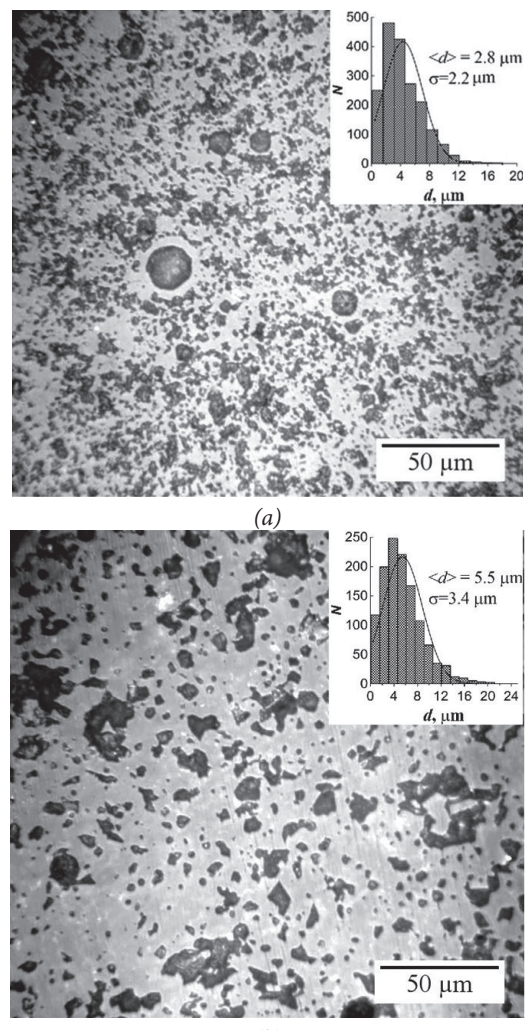

(b)

Fig. 1. The pore structure of $\mathrm{Al}_{2} \mathrm{O}_{3}$ ceramics with unimodal porosity sintered at (a) $1400^{\circ} \mathrm{C}$ and $(b) 1600^{\circ} \mathrm{C}$.

1. ábra Egyszerü porozitású Al2O3 kerámiák pórusszerkezete (a) $1400^{\circ} \mathrm{C}$-on és (b) $1600^{\circ} \mathrm{C}$-on történő szinterelés után. 
After sintering, the ceramics with hierarchical porosity had a porosity of $35-60 \%$. The inter grain fine porosity appeared in the sample volume as a result of the diffusion and recrystallization processes during sintering and is determined by the sintering temperature. The UHMWPE particles played the role of poreforming agents promoting the production of coarse porosity in the sintered ceramic samples. The ratio between coarse and fine porosity was changed by selection of the process parameters (temperature and the number of pore- forming agent particles), which made it possible to achieve the "zonal-segregation" effect upon the shrinkage of the samples. The mean size of large pores was about $80-100 \mu \mathrm{m}$ (Fig. 2,a), and the size of small pores was $10-15 \mu \mathrm{m}$ on average (Fig. 2b). The inter- group porosity resulting from the "zonal segregation" effect in the volume of sintered ceramics was present in the form of elongated pore channels connecting large pores with each other and forming a block structure thereby (Fig. 2, a). The mean size of blocks of the sintered material was determined by the distance between the large pores and was in the range from 110 to $120 \mu \mathrm{m}$.
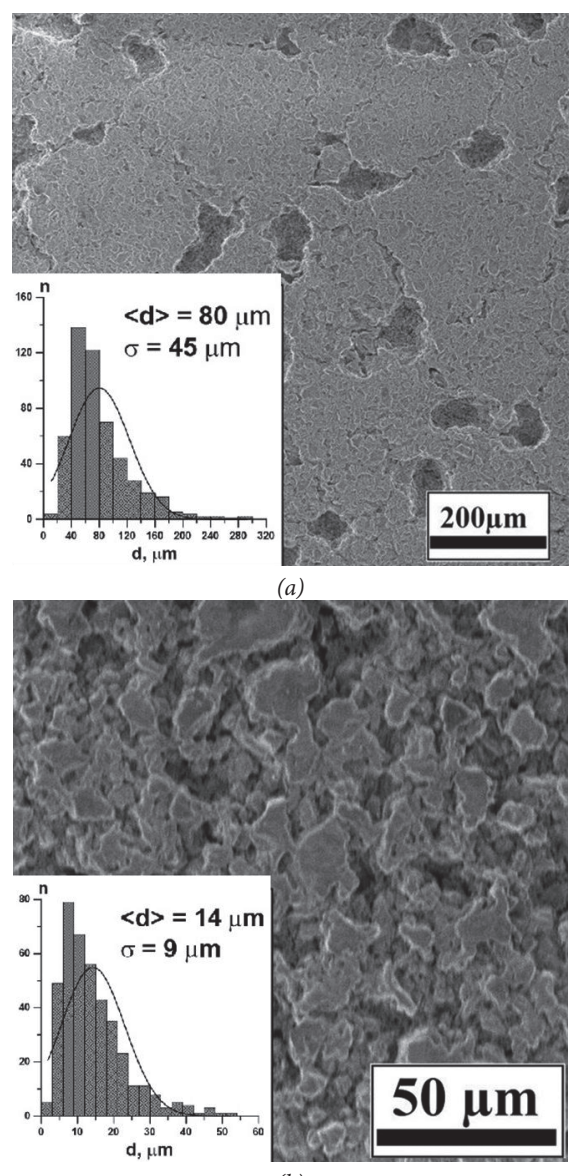

(b)

Fig. 2. Typical images of the $\mathrm{Al}_{2} \mathrm{O}_{3}$ ceramics with hierarchical porosity: (a) "coarse" and "interblock" porosity, and (b) "fine" porosity. The inserts show the typical size distributions of (a) "large" and (b) "small" pores.

2. ábra Hierarchikus porozitással rendelkezö $\mathrm{Al}_{2} \mathrm{O}_{3}$ kerámia (a) durva és interblock porozitással illetve finom porozitással (b). A jellemzö pórus-méreteloszlás (a) durva és (b) finom pórusok esetén.

The appearance of the stress-strain curves and the fracture behavior of the ceramic samples with the unimodal and hierarchical porosity depended on the porosity level. For the $\mathrm{Al}_{2} \mathrm{O}_{3}$ ceramics with unimodal porosity with porosity varying between 10 and $30 \%$, the stress-strain curves exhibited a linear relationship up to multiple fracture of the material (Fig. 3, a, curve 1). An increase in the porosity more than $30 \%$ leads to a deviation from linearity in the pre-fracture stage (Fig. 3, a, curves 2 and 3 ).

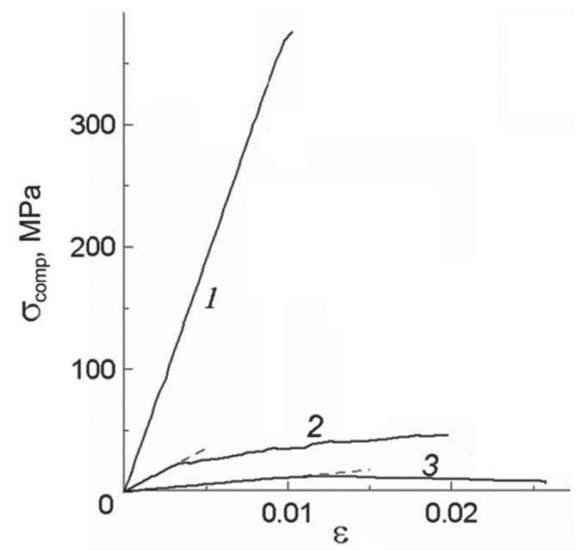

(a)

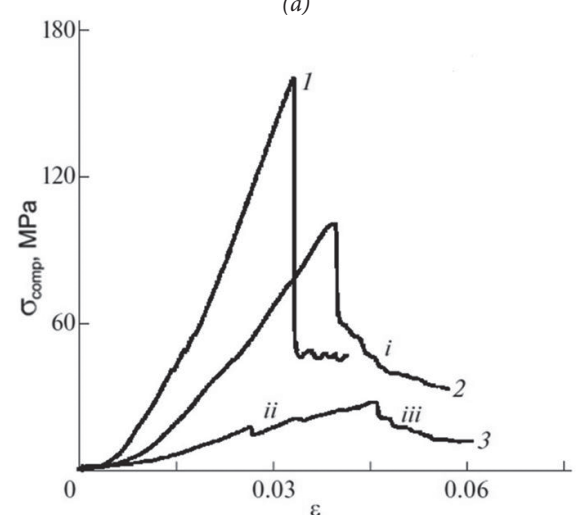

(b)

Fig. 3. Stress-strain curves obtained after the compression tests of $\mathrm{Al}_{2} \mathrm{O}_{3}$ ceramics with: (a) unimodal porosity 20 (1), 50 (2), and 65\% (3) and (b) hierarchical porosity (1) 35 , (2) 48 , and (3) $58 \%$.

3. ábra $\mathrm{Az} \mathrm{Al}_{2} \mathrm{O}_{3}$ kerámiák préselése során kapott erö-deformáció görbék (a) egyszerü porozitás 20 (1), 50 (2) és 65\% (3) és (b) hierarchikus porozitás 35 (1), 48 (2) és $58 \%$ (3) esetén.

The ceramic samples with a hierarchical porosity of up to $40 \%$ show stress-strain curves characterized by the elastic behavior until the breakdown (Fig. 3, b, curve 1). The samples with porosity of $40-50 \%$ are characterized by an increase in the microdamage accumulation region after a solitary macroscopic fracture (Fig. 3, b, curve 2, section i). In the samples with a porosity of more than $50 \%$, microdamage appears already at the active stage of loading (Fig. 3, b, curve 3, section ii), and the stress smoothly drops at the final section of the stress-strain curves after reaching the ultimate tensile strength (maximum loading) (Fig. 3, a, curve 3, section iii).

The dependence of effective elastic modulus $\left(\mathrm{E}_{\text {eff }}\right)$ and compressive strength values $\left(\sigma_{\text {comp }}\right)$ and on the pore-space volume for alumina ceramics with unimodal and hierarchical porosity illustrated in Fig. 4. The values of the compressive strength and effective elastic modulus of the ceramics decrease exponentially upon an increase in the pore-space volume of the samples. At fixed values of the pore-space volume, the studied ceramics with hierarchical pore structure shows a noticeably higher compressive strength as compared to the ceramics with a unimodal porosity. 
After compression tests, the structure of the ceramic with unimodal porosity and low porosity values contained macrocracks. The structure of the high-porosity specimens exhibits multiple microcracking.

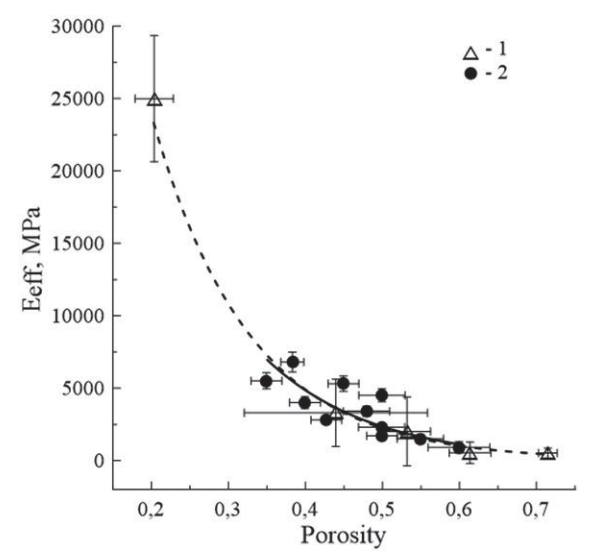

(a)

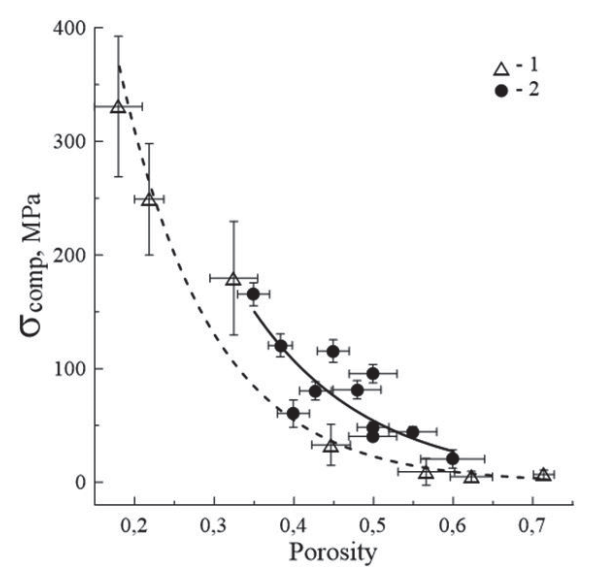

(b)

Fig. 4. The dependence of effective elastic modulus $\left(E_{\text {cff }}\right)$ and compressive strength values $\left(\sigma_{\text {comp }}\right)$ and on the pore-space volume for alumina ceramics with (1) unimodal and (2) hierarchical porosity.

4. ábra Az effektív rugalmassági modulus változása a nyomószilárdság és az $\mathrm{Al}_{2} \mathrm{O}$ kerámia pórustérfogata szerint (1) egyszerü és (2) hierarchikus porozitásnál.

The study of the microstructure of the $\mathrm{Al}_{2} \mathrm{O}_{3}$ ceramics with hierarchical porosity after compression tests showed that blocks formed during sintering are separated from each other by mesoscopic fractures and discontinuities (Fig. 5, a) that are formed at the boundaries between adjacent blocks owing to the deformation localization in the process of loading. The block structure formed during sintering collapses along the block boundaries because of the destruction of brittle bridges connecting the blocks with each other, forming, as a result of the fracture, fragments comparable in size with a mean size of grains (10 - $20 \mu \mathrm{m}$, Fig. 5, b), which leads to broadening of the fracture zones between blocks up to 40 to $50 \mu \mathrm{m}$ (Fig. $5, \mathrm{~b})$. Such a destruction mechanism reduces the extent of destruction, enhancing the capability of totally brittle ceramics to efficiently resist an applied load, which is evidenced by the increased compressive strength values.

Thus, analysis of the stress-strain curves for the porous alumina ceramics with unimodal and hierarchical porosity has revealed a transition from characteristically brittle fracture of low-porosity specimens attendant with formation of the main crack to the development of multiple fracture sites configured as microcracks in high-porosity specimens. The macroscopic deformation behavior of ceramics exposed to loading is referred to as pseudo-plastic and is similar to that observed in plastic materials. The obtained hierarchical structure of porous ceramics exerts a significant influence on the character of damage produced in the material under compression, bringing about a transition from a brittle state to quasi-plastic failure due to the formation of numerous focal areas of destruction, and the formation of hierarchical deformation structures in the ceramics volume leads to the effect of reducing the destruction processes from the macroscopic scale, in the case of unimodal ceramics, to a mesoscale fracture comparable with the size of blocks formed during sintering. A separate study should be devoted to a more detailed analysis of the mechanisms of formation of such deformation structures.

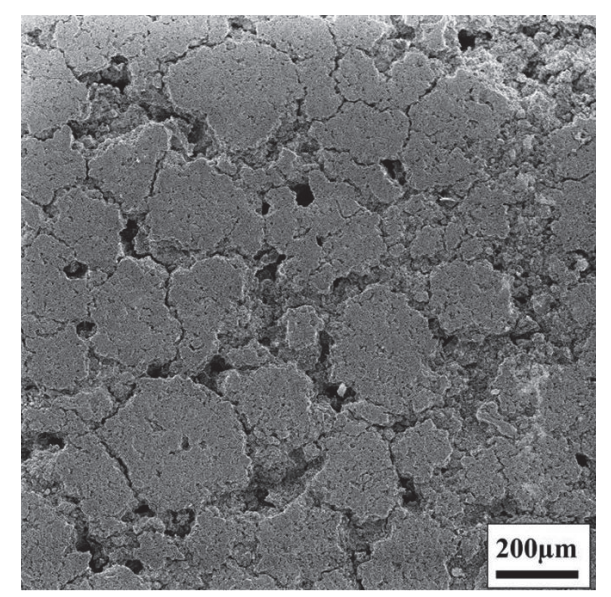

(a)

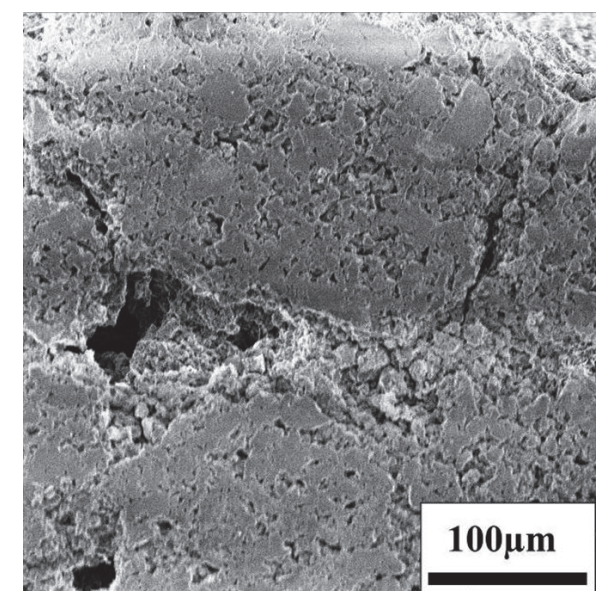

(b)

Fig. 5. Structure of porous ceramics with a hierarchical porosity of $60 \%$ after the compression tests.

5. ábra Porózus kerámiák mikroszerkezete $60 \%$ hierarchikus porozitással a tömörités után.

\section{Conclusion}

The analysis of stress-strain curves of porous alumina ceramics are shown that during deformation in compression tests; there was a transition from a typically brittle state for dense ceramics to a pseudo-plastic state with a high porosity level. 
It is shown that the obtained hierarchical porous structure causes the formation of a hierarchical deformation structure in the volume of ceramics and leads to a decrease in the extent of destruction processes from the macroscopic scale in the case of unimodal ceramics to the microscale destruction comparable with the sizes of the blocks formed during sintering.

At fixed values of the pore space, the studied ceramics with hierarchical pore structure shows a noticeably higher compressive strength as compared to the ceramics with a unimodal porosity.

\section{Acknowledgement}

This work was carried out with partial support of project \#14.584.21.0026 (RFMEFI58417X0026).

\section{References}

[1] Ohji, T. - Fukushima, M.: Macro Porous Ceramics: Processing and Properties. Int. Mater. Rev., 2012, V. 57, pp. 115-131.

[2] Hammel, E. C. - Ighodaro, O. L.-R. - Okolin, O. I. : Review paper Processing and properties of advanced porous ceramics: An application based review. Ceramics International, 2014, V. 40, pp. 15351-15370.

[3] Kulkov, S. N. - Grigoriev, M. V.: Sintering of Al2O3 ceramics based on different sizes powders Epitoanyag, 2010, No. 3, pp.66-69.

http://dx.doi.org/10.14382/epitoanyag-jsbcm.2010.13

[4] Kulkov, S. N. - Maslovskiy, V. I. - Buyakova, S. P. - Nikitin, D. S.: NonHookean behavior of porous zirconium dioxide under active compression deformation. Technical physics journal, 2002, V. 72/3, pp. $38-42$.

[5] Kulkov, S. - Maslovskii, V. - Buyakova, S.: The non-Hooke's behavior of porous zirconia subjected to high-rate compressive deformation. Technical Physics, The Russian Journal of Applied Physics, 2002, V. 47, № 3, pp. 320324.

[6] Savchenko, N. L. - Sablina, T. Yu.- Sevost'yanova I. N. -Buyakova, S. P. Kul'kov S. N.: Deformation and fracture of porous brittle materials under different loading schemes. Russian Physics Journal, 2016, Vol. 58, No. 11, pp.1-5 (Russian Original No. 11, November, 2015).

[7] Tariq, Fatima - Rafique, Uzaira - Yaqoob, Khurram: Synthesis of alumino-silicates functionalized titanium as potential adsorbent: An industrial possibility. Épitőanyag $\$$ Journal of Silicate Based and Composite Materials, 2017, V. 69, No. 3, pp. 94-97.

https://dx.doi.org/10.14382/epitoanyag-jsbcm.2017.16

[8] Tallon, Carolina - Chuanuwatanakul, Chayuda - Dunstan, David E. Franks, George V.: Mechanical strength and damage tolerance of highly porous alumina ceramics produced from sintered particle stabilized foams. Ceramics International, 2016, V. 42, pp. 8478-8487.

[9] Meille, S. - Lombardi, M. - Chevalier, J. - Montanaro, L.: Mechanical properties of porous ceramics in compression: On the transition between elastic, brittle, and cellular behavior. Journal of the European Ceramic Society, 2012,V. 32, pp. 3959-3967.

[10] Torres-Cadenas, S. - Bravo-Patiño Alejandro - Zarate-Medina, Juan Contreras-García, María Eugenia: Nest-like $\mathrm{BaO} \cdot 6 \mathrm{Fe}_{2} \mathrm{O}_{3}$ microspheres with hierarchical porous structure for drug delivery. Épitöanyag $\$$ Journal of Silicate Based and Composite Materials, 2017, V. 69, No. 1, pp. 2-6. https://dx.doi.org/10.14382/epitoanyag-jsbcm.2017.1

[11] Grigorev, M. V. - Savchenko, N. L. - Buyakova, S. P. - Kul'kov, S. N.: Inelastic Behavior of Ceramics with Hierarchical Pore Structure under Compression. Technical Physics Letters, 2017, Vol. 43, No. 8, pp. 723-726.

[12] Saltykov, S. A.: Stereometric Metallography (Metallurgiya, Moscow, 1976) [in Russian].

Ref.:

Grigoriev, Mihail V. - Savchenko, Nikolai L. - Sablina, Tatiana Yu. Kurovics, Emese- Sevostyanova, Irina N.- Buyakova, Svetlana P.- Gömze, László A.- Kulkov, Sergei N.: Deformation and fracture of alumina ceramics with hierarchical porosity

Építőanyag - Journal of Silicate Based and Composite Materials, Vol. 70, No. 1 (2018), 18-22. p.

https://doi.org/10.14382/epitoanyag-jsbcm.2018.4

Hierarchikus porozitású alumínium-oxid kerámiák deformációja és törése

Jelen munkában a szerzốk a porózus alumínium-oxid kerámiák tömörödési tulajdonságait és viselkedését tanulmányozták. A hierarchikus pórusszerkezetet háromféle pórus típus alkotta: durva porozitás

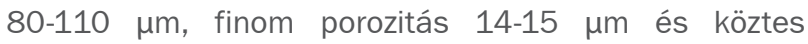
„interblock” porozitás, amely hosszúkás (110-120 m) mikrocsatornákból áll és a szinterelés során a zónaszưrés eredményeként alakul ki. Mechanikai terhelések során az ilyen hierarchikus porózus szerkezetú kerámiában hierarchikus deformációs struktúra jön létre. A vizsgált hierarchikus pórusszerkezettel rendelkezố kerámiák jelentôsen nagyobb nyomószilárdságot mutattak, mint az egyszerū vagy hagyományos porozitású kerámiák.

Kulcsszavak: deformáció, törés, póruskerámia, alumínium-oxid.

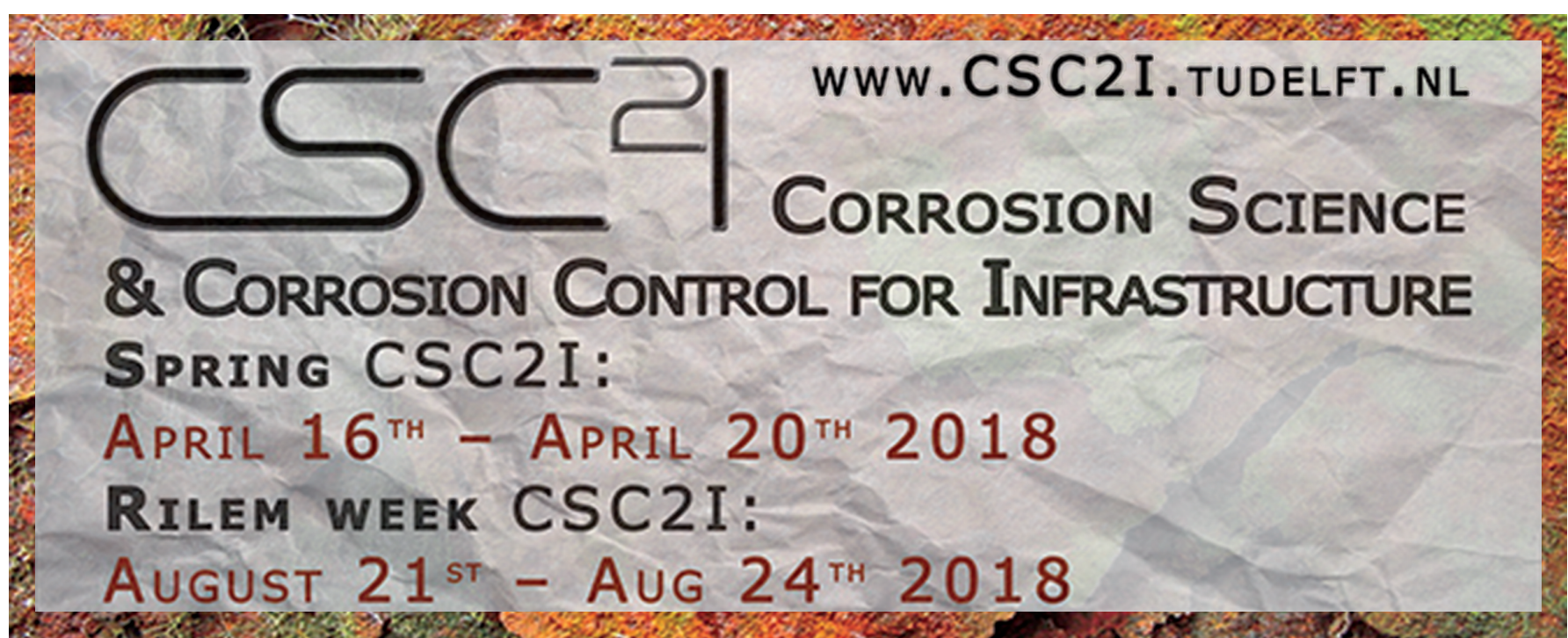

